\title{
Vasilijus Safronovas
}

Institute of Baltic Region History and Archaeology, Klaipéda University

Klaipeda

safronovas@gmail.com

\section{Who fought for national freedom? On the significance of the Great War in interwar Lithuania}

\section{Introduction}

In 1938, Lithuania commemorated the twentieth anniversary of its independence. The occasion was marked by several publications to introduce the country to readers both at home and abroad. One of them was a book published in Lithuanian (Kemežys, 1938) which focused on the achievements of the two decades: the contributors wrote about the progress that had taken place in all areas over the period, from the army and education to welfare, architecture and art. Lithuanian history did not receive any special attention. However, the chapter on the army included a rather exhaustive historical overview of the Wars of Independence, written by the professional historian and lieutenant in the reserve Antanas Vasiliauskas, who worked at the army headquarters at the time. The very first paragraph catches the eye:

After the storm of the Great War quietened down, Lithuanians freed themselves from the claws of the double-headed eagle, and undertook to build an independent state. [...] Lithuania's sons, sacrificing their lives on the altar of their homeland, took up arms for a crucial struggle and won. (Vasiliauskas, 1938, p. 46) 
The author had in mind the military action on Lithuanian territory in the period 1919 to 1920 . Meanwhile, another publication by Lithuanian authors, devoted to the twentieth anniversary and published in German, was to introduce readers abroad to Lithuanian history and culture (Vykintas, 1938). This publication devoted much more attention to history: altogether about half the book. The foreword stated: "It is just necessary to point out that after the partition of the state in 1795, despite the loss of its independence, Lithuania continued fighting intensely for its national and statehood rights. Lithuania's Declaration of Independence on 16 February 1918 was the logical result of the struggles and aspirations of the Lithuanian nation" ("Vorwort", 1938, p. 5). In the German-language account of Lithuanian history, the Wars of Independence received a mere two lines, which depicted the merits of Antanas Smetona, who, of course, did not even participate in the wars (Merkelis, 1938, p. 19). Despite this, the "Leader of the Nation" was portrayed as the main fighter for Lithuania's unity and independence, the key figure in the fight for freedom. Moreover, the historian Adolfas Šapoka (1938, p. 122) called one of the subdivisions of his chapter "The World War and the Restoration of Lithuania's Independence". Altogether, it was supposed to create the unambiguous impression that the essential fight for Lithuania took place before rather than after 1918, and that Smentona played a key role in it.

But then who did contemporaries actually understand were the main actors that fought for Lithuania's freedom? Were they the professional army and volunteers in the Wars of Independence in 1919-1920, or Smetona and the others before 1918? When was Lithuania's freedom gained: after the First World War, or during it, as is argued by Šapoka? It seems that the two publications produced in Lithuania in 1938 witnessed the simultaneous existence of several concepts of the contributions by different actors to national independence.

The understanding of this, at first sight trivial, idea may, in my opinion, be a starting point for a reconsideration of the answer to the question of the significance attached to the Great War in interwar Lithuania so far proposed by historians. In his presentation given at a conference as early as 1998, Darius Staliūnas (2001, p. 120) stated that in interwar Lithuania, "the focus was on those who perished in the fights for independence, but not in the First World War". Ten years later, Vejjas Gabriel Liulevičius (2009, p. 232) elaborated further on the statement: he believed that the period of the Great War in Lithuania was perceived as a "passive experience", which allegedly "was followed by the active engagement of the Wars of Liberation from 1918-1920". Tomas Balkelis (2014, pp. 242, 244, 246) several years ago specified that the marginalisation of the Great War was accounted for not by all the Wars of Independence, but by the conflict between Lithuania and Poland over Vilnius: according to him, it was the mythologisation of this conflict that overshadowed the remembrance of the Great War. Recently, Rasa Antanavičiute (2016) provided additional arguments showing that the Great War was not considered as important as the Wars of Independence in interwar Lithuania. 
But she actually followed the path laid down by her predecessors. I mean, first of all, that the above-mentioned researchers, when discussing the Lithuanian discourse in the interwar period, saw the prevailing trend only. This approach, however, does not help us see Lithuania as a normal society, in which at that time, like now, different meanings assigned to major events of the past circulated, and in which the relationship between those meanings was not, after all, as clear as it sometimes seems.

This article has no intention of addressing all still uncovered aspects of the politics of history in interwar Lithuania. So far, several attempts have been made to show the changing interpretations of different symbols and public holidays in this period (e.g. Nikžentaitis, 2002; Sirutavičius, 2001; Staliūnas, 2008). Besides, historians have analysed public mobilisation campaigns that utilised specific historical meanings (e.g. Mačiulis, 2001, 2009). Still, these studies do not show the contradictions that existed in the understanding of history, nor do they distinguish between the roles of individual actors and the ruling elites in its changing utilisation. My starting points were based on the premise that different actors in national states at the beginning of their existence had completely different ideas about how the state had been created, and what the merits of those actors had been in establishing those states. On turning into narratives, through communication acts in the long run, these visions become increasingly homogeneous and purified, and some of them make up the truths of textbooks; however, the process takes time.

In my understanding, the essential contradictions in interwar Lithuania arose from two issues relating to the building of a national state. The first was the date of the starting point of the state: was it 16 February and the State Council of Lithuania, or 15 May and the Constituent Assembly. Second, who fought for the national freedom of Lithuania? Both issues are partly interrelated, however: the first tended to embrace discussions on the role of specific politicians and institutions, while the second was actualised by involving a much wider cohort of public actors. The article should not be treated as a pretentious attempt to fill all the gaps. Rather, it provides arguments for the statement that it was not only those who fought in the Wars of Independence that were treated as freedom fighters in interwar Lithuania. I seek to show that the expression of alternatives on this issue was characteristic of Lithuania all through the period of independence. Over more than twenty years, both before and after the coup of 1926, stories circulated simultaneously in the public discourse that provided different interpretations of which actors played the leading role in the fight for Lithuania's freedom.

\section{Different fighters: role attribution in historical storylines}

Narratives legitimising political and social systems frequently feature the motif of the fight as the main one. It can account for both the already-accomplished achievements 
and for the trajectory of domestic or foreign policies that the ruling actors are leading the nation along. This motif performs the nation-rallying function most effectively when the experiences characteristic of as large groups of people as possible are given prominence in the use of it. When citizens understand that their experiences are also presented in the legitimising narrative, the understanding greatly facilitates their engagement with the ideas that are being legitimised.

An attempt was made to merge the multitude of experiences of the generations that lived in interwar Lithuania into wider narratives of the fight for freedom. The fight in this case was understood not just in a military sense; the word was applied to any activity which could be described as performed for the sake of the community, the nation, or Lithuania. Not only different political actors, but all those who felt it was their duty to speak publicly on one issue or another, would combine different experiences of the fight understood in that way, and merge them into certain storylines. Storylines assigned the role of fighters to the nation, and sometimes just to its individual leaders, or the behaviour of the nation, relying on the Volksgeist concept, interpreted based on the motif of the fight. In the body of texts published in interwar Lithuania, three main storylines of that type can be identified:

(1) The first storyline covered the activity that started after the uprising of 1863-1864 in Lithuania, and continued until the early twentieth century: it was interpreted as both national consolidation and unarmed national resistance to Imperial Russian policy. The resistance, perceived in a simplified way as the fight against "Russification", was summarised from the first decade of the twentieth century at the latest as a storyline called "national revival" (tautinis atgijimas), "awakening" (tautinis atbudimas) or "rebirth" (tautinis atgimimas).

(2) The second storyline covered the Lithuanian government-organised armed defence of the territory claimed by it. The defence held out on several fronts from January 1919 until late 1920, while its individual components in a narrative sense were merged almost immediately afterwards into one storyline, called "the struggle for independence" (nepriklausomybès kova), "fights for independence" (nepriklausomybès kovos), or "the wars of independence" (nepriklausomybes karai).

(3) The third storyline embraced both armed and unarmed efforts to fight for the freedom of Lithuania and Lithuanians in the transitional period, that is, in the years of the Great War. In that case, the most different Lithuanian experiences of the period of the global conflict, the Great War, in accordance with the logic of per aspera ad $a s t r a$, were merged into the storylines of "regaining independence" (nepriklausomybès atgavimas), "restoration of the state" (valstybes atstatymas), "towards independence" (i nepriklausomybe), and the like.

Thus, three storylines basically expressed the events assigned to three different periods, with the participation of diverse actors performing dissimilar actions: starting with the transport of banned Lithuanian books in the Latin alphabet across 
the German-Russian border, or the attempts to articulate political ideas and act on behalf of all Lithuanians, and finishing with the armed struggle for these political ideas. Later in the article, I shall provide an interpretation of the dynamics of the public expression of these storylines.

\section{Democratic pluralism before the coup of 1926}

The material available to me does not indicate that any of the three storylines defined above prevailed over others in the first half of the third decade. Before the coup of 1926, all were more or less equally covered in the Lithuanian public discourse. In the case of the first storyline, even though it was not totally clear from interwar publications what the authorities of the Russian Empire wanted to Russify, the land or the people, the key event to remember was the resolution by the Russian Cabinet of Ministers, approved by Nicholas II on 7 May 1904, called the "press restoration" or "press recovery". The anniversary of 7 May was remembered in the interwar period more than once, in fact many times, thus reminding people of a more general storyline, and applying the motif of a fight to explain its process. The very resolution of 1904 was called "a victory by the nation" in the long fight with "giant Russia" (cf. Čiabuvis, 1924, p. 1; Rt., 1924, p. 1; “Šiandien 20 m. suejo...”, 1924, p. 1; “Spaudos sukaktuvès”, 1924), while the perception of the fight resulting in victory can be illustrated by a quotation from Trimitas (Trumpet) magazine on the occasion of the twentieth anniversary of 7 May. It stated that in Lithuania, "a persistent struggle for the restoration of the press had been going for decades, which required numerous victims, and which raised plentiful resolute people and spiritual giants" (“Spaudos sukaktuvės", 1924, p. 1).

To illustrate the third storyline, I shall deliberately use a quotation from the same Trimitas magazine from the same year. On the occasion of the tenth anniversary of the beginning of the conflict, Trimitas wrote about the Great War and its significance:

When commemorating the war, we have to remember how successfully, under the circumstances of that time and through the efforts of our patriots, we managed to liberate ourselves from the Russian yoke. [...] In one way or another, our country, just like other small countries, liberated itself during the Great War, and for us the Great War will always be a more remarkable event than for anybody else. (̌̌. Š., 1924, p. 11)

Thus, we see the same narrative: liberation and the struggle for freedom. And finally, the second storyline will be illustrated by another quotation from Trimitas of the same year. In one of its issues, the magazine commented on three postcards produced by the Lietuvos karo invalidų Vyčiu brolija (Lithuanian Vyčiai Brotherhood of War Invalids), which presented the first victims of the Wars of Independence Povilas Lukšys, Antanas Juozapavičius and Pranas Eimutis individually, and a fourth postcard, where they were presented all together. All of them were defined by Trimitas 
in a laconic manner: "Our first soldiers who died an honourable death in the battles for the independence of Lithuania" ("Knygos, raštai", 1924, p. 47). Thus, they also represented the fight for freedom and the victims of the fight. I have illustrated the three storylines with quotations from the same magazine from the same year not because there is no more material to illustrate them. I chose Trimitas, published by the public organisation Lietuvos šaulių sąjunga (The Lithuanian Riflemen's Union), only to show that, at least in the mid-1920s, all three storylines about the fight for freedom were still developed simultaneously in parallel.

The statement applies both to the discourse intended for a wider audience and to professional literature. This is proven by the content of the first five volumes (appearing in the years 1925 to 1929) of the journal Karo archyvas (Military Archives), published by the Department of Military Sciences of the Lithuanian Army Staff. In these volumes, attention was paid both to the uprising of 1863-1864 (the opinion prevailed that the "Russification" of Lithuania started after that), and to episodes in the Great War, especially the formation of Lithuanian national units in Russia in the years 1917 to 1919, as well as to the Wars of Independence, which in fact, at least in latter volumes of Karo archyvas, had not yet merged into one storyline. Moreover, when the War Museum was established in Kaunas at the beginning of 1921, which eventually became the main historical museum in Lithuania, it received first of all a very widely formulated task. The Ministry of National Defence gave instructions to show "how Lithuania, for centuries tormented by enemies, threw off the chains of slavery, and through pains and battles, with arms in hands, gained independence" (Isakymas Kariuomenei, 1921, \$2). The detailing in the order of the future exhibition plan did not add any more specificity. In the first (introductory) part of the museum exhibition, "The Gallery of the Fighters for Lithuania's Freedom and Independence" was to be presented (Isakymas Kariuomenei, 1921, $\$ 3$ ), without naming specifically who was regarded as fighters. Only later was it explained that they were "our heroes, our fighters for freedom, both intellectuals and ordinary villagers, if they contributed to the distribution of writings when it was forbidden, or suffered for the sake of Lithuanianness and freedom" (Isakymas Kariuomenei, 1922). In short, the narrative of the fight for freedom was perceived broadly, leaving space for integrating individual episodes that took place during the Great War and matched the general concept.

All three storylines were also reflected in an early version of "Who's Who in Lithuania", the Lietuvos albumas (Album of Lithuania) published in 1921. With regard to the place of the Great War in the album, it should be noted that in the short biographies of all ten officers included in the book, the experience of service in the Russian army during the First World War was highlighted. Thus, the biography of Colonel Vincas Grigaliunas-Glovackis gave a rather detailed account of what he did and where he served during the Great War (Markevičaite \& Gira, 1921, pp. 319-320). The biography of Pranas Klimaitis presented his activities in the organisation of 
national units in the Russian army, and later in the battles against the Bolsheviks in Siberia (Markevičaite \& Gira, 1921, pp. 338-340). As is indicated in the biography of Lieutenant Colonel Kazys Ladyga, "he received all the military awards that were presented to senior officers in the Russian army except St George's Sword". Moreover, when talking about the Great War, it added (sic!): "He made efforts to serve well, so as not to defame the name of a Lithuanian" (Markevičaite \& Gira, 1921, p. 349). The biographies of other officers-veterans of the Great War paid more attention to representing the postwar experiences and the contribution of the army of the Lithuanian state. However, at least in the Lietuvos albumas of 1921, they were not in the majority.

The representation of all three storylines, and not just one of them, can be seen in the renaming of streets in Kaunas in 1919-1922, and the early initiatives to have the first Lithuanian monuments built in Kaunas. The first storyline was presented by giving the names of Simonas Daukantas, Motiejus Valančius, Maironis and Adomas Jakštas to streets, as approved in April 1919 (KAA 219-1-90-11/12 1919), on having partially taken into consideration a corresponding proposal from the minister of the interior Aleksandras Stulginskis, submitted to Kaunas City Municipality. The production of sculptural busts of Jonas Basanavičius, Vincas Kudirka and Simonas Daukantas soon afterwards, initiated by the War Museum, also reflected this storyline. The third storyline was represented by the names of 16 February Street and Freedom Avenue, approved in 1919 (KAA 219-1-90-11/12 1919), and the names of Unity and Independence Squares (LCVA 379-2-567-48/50 1922), given on the eve of 16 February 1922, as well as the model of the Statue of Liberty made by the sculptor Juozas Zikaras at the initiative of the War Museum. The second storyline was given prominence by the names of Private Lukšys Street and Officer Juozapavičius Avenue, given at the initiative of the Head of the War Museum Lieutenant General Vladas Nagevičius in February 1922 (LCVA 379-2-567-48/50 1922), ${ }^{1}$ and, of course, by the unveiling of the Monument to Those who Perished for the Freedom of Lithuania at the War Museum on 16 October 1921. In his unveiling speech, President Aleksandras Stulginskis emphasised distinctly its dedication to those who perished in the battles of 1919 to 1920 (Stulginskis, 1921, p. 1). The ritual of commemorating national holidays by the monument started to develop as early as 1922 .

Thus, at least in the period before the coup of 1926, attention was paid to all three storylines. At approximately the same intensity, or at least without any clearly expressed preference for any of them, the storylines kept unfolding in the public discourse: in polemical writing or in the commemoration of anniversaries important to Lithuanians. Whether there were any differences between individual political parties is still to be found out through further research. One thing is clear: all through the period of

\footnotetext{
1 Nagevičius' proposal was also published in the press (“Karo istorijos reikalu”, 1922, p. 2).
} 
parliamentary democracy in Lithuania, not a single public holiday clearly relating to one specific storyline was introduced. Discussions by politicians on the subject did occur, but their initiatives on public holidays depended heavily on political fragmentation: from the decision of the Popular Socialists to establish 1 May as a national holiday in 1919 (LCVA 923-1-68-58 1919) to the aspirations of the Catholic faction to eliminate all days off that did not match the ecclesiastical calendar. Therefore, it seems to follow that before 1926 political parties in Lithuania did not especially interfere with the coexistence of these three storylines. On the contrary, the fact that most political actors did not have experience of fighting in the Wars of Independence led to the promotion of that coexistence in different ways, such as by the statement in Gabriele Petkevičaitès Constituent Assembly opening speech. Although the first meeting of the Constituent Assembly started with a minute's silence to honour the volunteers who died for the freedom of the homeland in 1919-1920, the famous author and publicist who was invited to chair the meeting as the oldest member of the Assembly was not too modest to call herself "an old fighter for her nation's independence" ("I sesijos Pirmasai posédis", 1920, p. 2). Petkevičaite had in mind primarily the fight for democracy, equal rights, and the emancipation of subjugated people, with the greatest emphasis on the motifs of the fight relating to the first storyline.

\section{The impact of the coup: priority to volunteers}

In fact, the situation started changing only after the coup. A fundamental change was caused by the fact that the army was the main force that brought Antanas Smetona to power in December 1926. To be specific, the principal role of the implementers of the coup was played by the Slaptoji karininku sąjunga (Secret Union of Officers), with the prevalence of officers of the younger generation, who typically counted their contribution to the fight for Lithuania from 1919. Their active role in the organisation of the coup was basically predetermined by the policies pursued in Lithuania by the left-wing government, which was established in June 1926. The abolition of martial law, the introduction of freedom of speech and meetings, highlighted the diversity of opinions and interpretations. The political decisions by the socialists, which caused the army a lot of anxiety, among other things, led to the relatively rapid rallying of participants in the Wars of Independence to organise a lobbying association, the Lietuvos kariuomenès savanorių sąjunga (Association of Lithuanian Army Volunteers) (cf. Jurevičiùte, 2009). Having come to power in an unconstitutional way, the Tautininkai (Nationalists) tried to keep in favour with both the army and the largest association of veterans.

That was one of the main reasons, firstly, why, immediately after the coup, increasing attention was given to the deceased victims who could be related to 
the existing Lithuanian army rather than to other fighters. Second, soon afterwards, and especially in 1928, the "status" of 23 November started to change. On 23 November 1918, Augustinas Voldemaras, the head of the government, signed the first decree on the Ministry of National Defence. Since as early as 1919, the army tried to regard this as the day of one of the most important legal acts on the establishment of the army, and generally on statehood. However, for at least a decade, it was basically an internal army holiday, or just a commemorative day. In the 1920s, its public importance was often overshadowed by the anniversaries of Basanavičius, who was also born on November $23,{ }^{2}$ and it started gravitating towards the status of a national holiday only after the coup, and especially in the 1930s, when it was called with confidence the second most important historical date after 16 February (cf. A. G., 1935, p. 3; "Drausminga kariuomenè ir drausminga tauta", 1937, p. 4; "Kariuomenès 15-os metų sukaktis", 1933, p. 4). Another change was related to the attempts to "pull" the Declaration of 16 February out of the third above-mentioned storyline, and to relate it to the second one, by making the narrative sound as if the army implemented the programme outlined by the signatories of the Declaration. It is clear that this representation was the beginning of placing the emphasis primarily on the role of Voldemaras and Smetona, who became established in power after the coup, in the fight for Lithuania. Incidentally, the death of Basanavičius in 1927 was favourable for the formation of the cult of Smetona, as there was no other person left whose authority could overshadow Smetona's role in the 16 February story. Thus, however strange it may sound, it seems that, by doing away with the double identity of 23 November, the death of Basanavičius freed the way for the Day of the Army to come out from "underground", and simultaneously made it possible to relate the role of Smetona to 16 February more clearly. As early as in 1928, Colonel Povilas Plechavičius, the chief-of-staff of the Lithuanian army and the former military commander in the coup, stated (Plechavičius, 1928, p. 2) that Smetona was also the "Leader of the Nation" in 1918. That implied that even then the actions of the army were inspired by him, while in 1926 the army simply returned the reins to him: it allegedly "said 'that's enough' to the destroyers of Lithuania [left-wing political circles] and invited the First Leader of the Nation to lead the Nation and the Army". A similar idea was encoded in the text of a publication that appeared on the occasion of the tenth anniversary of independence: the innocent text "After the authorities of Lithuania had formed, a persistent and bloody fight for freedom and independence

2 Thus, for example, on 23 November 1923, when unveiling the bust of Basanavičius, the fifth anniversary of the founding of the army was largely overshadowed by the army itself: "The War Museum invites the Aušrininkai [protagonists of the national movement], all the creators of Lithuanian independence, representatives of the press, and the public [...] to participate in the unveiling of a monument that the grateful army, on the occasion of its fifth anniversary, dedicates to the Father of the rebirth of Lithuania Dr Jonas Basanavičius" ("Daktarui Basanavičiui paminklo atidarymas", 1923, p. 1). 
began" (Burba, 1928, p. 34) essentially meant that there had been no fight for as long as there had been no authorities.

A symbolic link between the active army and 16 February was facilitated by the fact that the memory of the "first perished" heroes (the soldier Povilas Lukšys and the officer Antanas Juozapavičius) started to form a year after their deaths (Isakymas Kariuomenei, 1920, §27; “Pirmoji karo auka už nepriklausomą...”, 1920, p. 51; “Pirmoji karo auka nepriklausomai...", 1920, p. 5); thus, it was related to 16 February from the very beginning, as the "democratic alternative" of 15 May had not yet unfolded by that time.

All these changes acquired numerous expressions. In February 1927, a special commemoration of Lukšys and Juozapavičius was held in Kaunas ("Pirmųjų kraujo aukų sukaktuvės", 1927, pp. 2-3). On 16 February 1927, Smetona arrived at the War Museum and made a speech on paying homage to the dead ("Nepriklausomybès sukaktuvès Kaune", 1927, p. 4), although before that, similar ceremonies were taking place on 15 May. On 16 February the next year, a new ritual took place in the garden of the War Museum, during which Lieutenant General Nagevičius for half an hour read the names of those who had died in the Wars of Independence (J. K., 1928, p. 4). At the same time, a similar ceremony took place at the Kaunas City Council. On 15 May, residents of Kaunas participated in a mass torch procession to the city cemetery to honour those who fell in the Wars of Independence and were buried there (cf. "Gegužès 15 d. iškilmès Kaune", 1928, p. 2; "Tautos šventès iškilmès", 1928, p. 2), and on 27 October 1930, a special monument was unveiled there ("Spaliu 27 d. Kaune", 1930, p. 5). All this was not limited to Kaunas: over several years, at least seventy monuments to the decade of independence appeared all over the country, including dozens that were simultaneously dedicated to those who fell for freedom in the Wars of Independence (cf. Skirmantienè \& Varnauskas, 1994).

Therefore, for several years after the coup, increased attention by both the ruling authorities and the army was clearly paid to just one of the storylines which emphasised the Wars of Independence. Quite understandably, alternative fighters for the freedom of the homeland and the related storylines naturally crept into the background, and some of them, one might say, were marginalised, and marginalised deliberately. Thus, for example, at the solemn meeting of the Council of Bearers of the Order of the Cross of Vytis, the only Lithuanian state award at the time, dedicated to the tenth anniversary of the Lithuanian army, Smetona stated that

Lithuania has been involved in two wars: the World War and the War of Independence. Many worthy Lithuanian lives have been laid on the altar of the worldwide fire, and we mourn and grieve for them, while crowning them with martyrs' wreaths. The second war was the war of Lithuania itself, the war on the issue of its life. This honourable meeting [of the bearers of Orders of the Cross of Vytis] shows us that it is not only the crown of pain, but also of honour that adorns its participants. ("Kaip praejo kariuomenès šventè", 1928, p. 4) 
The words implied that the veterans of the Great War had to be sympathised with and treated as victims, while the participants of the Wars of Independence deserved respect. Another example is from 1930, when a ceremony for bringing in the picture of Grand Duke Vytautas, transported all over Lithuania in a ritual way, was held at the War Museum. During it, the picture was carried by wounded soldiers from the battles of the Wars of Independence, and one wounded soldier from the Great War. However, the latter was needed merely to assist "a blind invalid bearing a book". Besides, according to the semi-official press organ, "the invalid from the Russian army in the Great War" represented those who "had lost their health being made to fight for others" ("Didžioji Tautos šventè, 1930, p. 4), and therefore not for Lithuania. When in November of the same year a similar ceremony took place during the consecration of the cornerstone of the new Vytautas the Great Museum building, a capsule to be put in among the five stones brought from the "fronts of the Wars of Independence" was entrusted to people introduced as representatives of the Council of the Order of the Cross of Vytis, the Lietuvos kariuomenès savanorių sajunga, the Lietuvos karo invalidų sąjunga (Lithuanian War Invalids Association), the Lietuvos šaulių sąjunga, and the Atsargos karininkų sąjunga (Reserve Officers Association) (Alm., 1930, p. 5). There may have been a veteran of the Great War among them; however, the fact was not specially emphasised.

Yet even after the coup, not all citizens of the country believed that the question who had fought for the freedom of the Motherland should have been answered in the way that the ruling forces tried. This also applies to military people. Thus, in 1927, on the Day of the Army in the War Museum, Alfonsas Mažonis made a speech on behalf of the Atsargos karininkų sąjunga, in which he attributed the role of fighters for freedom not merely to Lukšys and Juozapavičius. According to him, there was

a whole host of known and unknown soldiers; those who perished on dark, rainy, gloomy autumn nights with bundles of smuggled books and newspapers in their hands on Prussian-Russian cordons; those who died in prisons-casemates of despotic Russia; and those who died after being deported to remote Siberia. [...] We, reserve officers, today come to bow at your graves, wherever they might be. ("Kaip mūsų kariuomenè praleido vakarykščią dieną", 1927, p. 5)

The term "veteran", which could normally be claimed by soldiers, was applied many times to the protagonists of the national movement (the Aušrininkai), and especially during the celebrations of the decade of independence; some of them, Basanavičius and Petras Vileišis, were called veterans even by Lieutenant General Nagevičius in an official speech on the occasion of 16 February 1928 (J. K., 1928, p. 4). When the twenty-fifth anniversary of the restoration of the press was celebrated in Kaunas in 1929, the semi-official press organ wrote: on the stage "one sees grey-haired old men, veterans of the nation, and creators of the press who raised and carried the whole 
struggle of the press on their shoulders. By creating the press and fighting for its freedom, these elderly people were also creating our independence, our independent state" ("Baisus ịspejimas", 1929, p. 1; see also Janušauskaite, 2016). The opposition press had some third storyline figures who would grant themselves the status of veterans. Thus Juozas Gabrys, "undoubtedly the best-known Lithuanian political figure on the European scene before 1916" (Senn, 1977, p. 16), who after 1918 felt pushed out of state affairs, called himself "a veteran of Lithuania" and "an old fighter for Lithuania's independence” (Gabrys, 1928, p. 4). A variety of freedom fighters' roles also appeared in publications devoted to the tenth anniversary of independence. Martynas Yčas, a previous deputy to the Russian State Duma from the Kaunas province, who organised assistance for the Great War refugees from Lithuania in the empire, argued that the "greatest preparatory work" in the building of the state was done not by Smetona, the Council of Lithuania, or the army, but rather by Lithuanians in the depths of Russia who, to quote him, "fought for Lithuania's independence" (Yčas, 1930, p. 24). Juozas Purickis, who spent the years of the Great War in Switzerland and got involved in the activities of the Council of Lithuania as late as July 1918, wrote (Vygandas, 1928, p. 69): "One cannot argue that freedom was granted to Lithuania by the Great War". Some other authors managed to present simultaneously two storylines on the same page of the same text: in one place they claimed that freedom was granted to Lithuania by the Great War, and in another that it was done by the "blood shed by hefty volunteers in the unequal fights of 1918-1920" (Kalnènas, 1928, p. 141).

Some words should be said about monuments. Rasa Antanavičiūte stated that during the period between the two world wars, more than two hundred new monuments were built in Lithuania, of which in only one case did she manage to establish a formally recorded reference to the Great War. This enabled her to conclude that monuments to the Great War in Lithuania during the interwar period are single exceptions, which, in her opinion, testifies to the fact that the Lithuanian authorities and the people clearly ignored the Great War (Antanavičiūtè, 2016, p. 189). Despite the fact that the number of monuments which included references to the Great War was much larger in Lithuania, they were all put up in war cemeteries or other places of burial, and from this point of view they were intended to honour the dead, not to tell the public what they had to remember. The only exception known to me, which has not been noticed by historians so far, was the initiative by the Lietuvos valstiečių sąjunga (Society of Lithuanian Peasants) in Skaudvile (Taurage district) to build a monument (1933) to three riflemen from the village of Stulgiai, who were tortured and shot by Bermondt-Avalov troops in December 1919. Although this is clearly indicated on the monument, the most interesting thing is the inscription on its pedestal: "Glory to the sons of Lithuania who died in the World War from 1914 to 1920" (Mažrimas, 1994). It is a rare case clearly witnessing the fact that in some people's consciousness the Great War ended not in 1918 but in 1920. All the other 
monuments to the victims of the Great War which were put up in Lithuania during the interwar period were erected in places of mass burials, or sometimes burials of individual soldiers. However, the Skaudvile case, as well as other examples, shows that these monuments appeared at the initiative of local communities. In many cases, this is a rather striking difference compared to the semi-coordinated campaigns for the construction of monuments to independence or the Wars of Independence, which were initiated mainly by nationwide networks, such as the Lietuvos šaulių sąjunga. In other words, in the interwar period in Lithuania, there was no organisational movement that systematically marked the most important places of battles in the Great War, or the deaths of Lithuanian soldiers, throughout the country.

However, this does not mean that there were no monuments in Lithuania representing the experiences associated with the third storyline. So far, historians have not noticed that there were in fact three types of monuments to the freedom and independence of Lithuania which appeared during the period between the world wars. Some of them, such as the above-mentioned Monument to Those who Perished for the Freedom of Lithuania put up at the War Museum in Kaunas (1921), implied an explicit reference to the Wars of Independence, and thus could not be used to commemorate the activities of Lithuanians during the Great War. Many others, such as the Statue of Liberty by Juozas Zikaras, unveiled near the same museum in 1928 (as well as symbols based on it, such as the one in Alytus), were monuments both to Lithuania's independence and the Wars of Independence. However, many monuments to Lithuania's independence did not have clear references to the post-First World War armed struggle, victories (Klaipeda), or the ongoing battles (for Vilnius), of modern Lithuania. I counted at least twenty-four such monuments erected in Lithuania in 1923-1934 (see Safronovas, Jokubauskas, Vareikis, \& Vitkus, 2018, p. 306). All of them were usually built on the occasion of the anniversary of independence, and represented 1918 as the year of gaining or winning freedom and independence for Lithuania. In this way, they developed the argument which became entrenched as early as 1918-1919, mostly by members of the Council of Lithuania, that the reference point for independent Lithuania was the 16 February 1918 Resolution of the Council of Lithuania. This made it possible to disseminate the notion that the activities of the members of the Council of Lithuania during the Great War were an attempt to fight for Lithuania's freedom, an effort to put an end to the suffering of Lithuanians under the German occupation. This was nothing less than the above-mentioned storyline per aspera ad astra.

What does this tell us? At the very least, that the attempts to establish one specific concept, as well as the concept itself, were far from acceptable to all public actors. And it was not acceptable because, with the emphasis placed on the exclusive contribution by the army, the merits of others who felt they also contributed to independence were ignored. Authoritarianism was not introduced immediately after the coup, and quite 
a few active public figures were not inclined to support the efforts of the ruling elite to distinguish clearly one group of fighters. I would say that the situation was similar to that observed after the Second World War, when the diversity of experiences was overshadowed by a homogeneous plot, where far from everybody was provided with an opportunity to reflect on the adequate representation of their role and their experiences. The third storyline, which embraced the explanations of who did what in the Great War, caused especially many controversies in the interwar period. These controversies stemmed from differences in experience, diverse attitudes towards the changing regimes chosen at the end of the war, and finally from different evaluations of the significance of one's and others' contributions.

What was the response of the ruling elite to the differences in experience which kept penetrating the public discourse? At the time, they were moving towards mild authoritarianism, and were inspired by the ideal of national unity. It seems that their response might have been promoted by the diversity that unfolded in 1928 , during the tenth anniversary of independence. The diversity might have testified to the fact that the ideal of national unity in the case of the issue of who had fought for the freedom of the homeland did not work in reality. This provoked a response that could be observed later in independent Lithuania. It was characterised by the tactics of choosing alternative symbols for national consolidation, whose opportunities for public exploitation would not be constrained by the controversies between the generations who lived at the time and their different experiences.

\section{To overcome controversies: an integrating politics of history of the 1930 s}

The tactic could be called "rising above controversies". Its primary expression could have been grasped in the exploitation of the 500th anniversary of the death of Vytautas the Great, in an attempt to consolidate the nation around the figure of the grand duke. As has already been revealed in historiography (cf. Mačiulis, 2001; Nikžentaitis, 1998; Viliūnas, 2001), the abundance of events dedicated to the memory of Vytautas was primarily meant to consolidate the cult of Smetona. It was no accident that two colour portraits of the two most important men in Lithuania, Smetona and Vytautas, painted by the artist Jonas Mackevičius, were published in a splendid large-format album which recorded the most significant episodes in changes to the state and society in Lithuania between the 1920s and 1930s from different angles (Sarafinas, 1933, pp. 3, 39). An initial analysis of the commemorative events held in 1930 clearly indicates that an attempt was made to subjugate all the controversies on the issue of who fought for the freedom of the nation to the cult of Vytautas, and simultaneously, of course, to that of Smetona. Thus, for example, in July 1930, a memorial to those who died in the Wars 
of Independence was erected in the Kaunas military cemetery. However, its unveiling ceremony held on 27 October was called "the mournful commemoration of the 500th anniversary of the death of Vytautas the Great". In the opening speech, Smetona (1930, pp. 1-2) did not say a single word about the buried people to whom the monument was dedicated, but talked a lot about what could be learnt from Vytautas. In fact, the trend started as early as 1928, when the Committee for Building the Resurrection Church in Kaunas publicly expressed the hope that the largest Catholic house of worship built in interwar Lithuania, to quote the Committee, the "monument to the regaining of Lithuania's independence", would be completed for the celebration of the anniversary of the death of Vytautas the Great.

Some other examples can be quoted. The 550th anniversary of the death of Grand Duke Kęstutis, commemorated in 1932, was not so pompous, but it also continued the same tactic. Another example of the tactics of "rising above controversies" might be the idea of turning the garden of the War Museum in Kaunas into a site commemorating the Unknown Soldier, first recorded probably in 1933, and implemented a year later.

This can be argued primarily due to the fact that Antanas Smetona, the "Leader of the Nation", even though he was assigned major roles in the most important commemorative state events, for some time did not participate in the rituals paying homage to the dead that took place in the garden of the War Museum. He last attended one in November 1928, on the occasion when, in the speech quoted above, he divided war veterans into honourable ones and those who were to be regarded as victims. Afterwards, the function of representative of the state in the rituals was performed by chief officers or members of the government, while Smetona, by his non-participation, seemed to want to create the impression that he did not prioritise the concept of the fighters for the freedom of the homeland represented by the Monument to Those who Perished for the Freedom of Lithuania. However, after a five-year break, on the occasion of the fifteenth anniversary of the army in 1933, he arrived and, as if having fallen from the sky, called the Monument to Those who Perished for the Freedom of Lithuania the Tomb of the Unknown Soldier, even though it had not performed such a function before (Smetona, 1933, p. 1). A year later, an unknown soldier was in fact buried there, with all due ceremony.

It has to be noted that Archbishop Pranciškus Karevičius agreed to consecrate the symbol, and he was thanked "especially warmly" for the involvement of the Church ("Jeigu vienybeje su vyriausybe...”, 1934, p. 4). Bishop Metropolitan Juozapas Skvireckas, Bishop of the Eastern Rite Pranciškus Bučys, and, of course, Martynas Jankus, who represented Prussian Lithuanians and protagonists of the national movement (the Aušrininkai) simultaneously, also participated in the consecration ceremony, next to heads of the state and the most senior military authorities, such as General Silvestras Žukauskas (the first commander-in-chief of the army). The participation of all these people obviously sought to create a semblance of national unity. Although in 
the Tomb of the Unknown Soldier, as was announced, "the bones of a soldier who died for the freedom of Lithuania in 1919" were buried ("Jeigu vienybeje su vyriausybe...", 1934, p. 4), during the consecration, attempts were made to attribute the meaning of a unifying symbol to it, without specifically focusing on any of the three storylines. Smetona (1934, p. 468) declared:

The Tomb of the Unknown Soldier [...] will commemorate all Lithuanian soldiers who died honourably - those who were buried here and there and are known, as well as those who are missing. [...] All who visit it and lay flowers and wreaths on it pay homage to the Tomb of the Unknown Soldier. That means the tomb deserves not merely national, but also human, universal respect. That is, respect to the human being who sacrificed his existence for the sake of the ideal of national freedom.

Archbishop Karevičius also spoke in a similar way: "Today we are burying an Unknown Soldier, the symbol of all those who perished for the freedom of Lithuania" (J. S., 1934, p. 920). Thus, it was another attempt at consolidation by choosing an anonymous hero, rising above specifically named heroes, and above evaluation-related controversies.

We can assume that, in the national consolidation project cherished by the Nationalists, an attempt was made to apply the tactics of "rising above controversies", as it provided more possibilities for manoeuvre: it was easier to provide the anonymous Unknown Soldier and the remote figures of Vytautas and Kęstutis with the desired content in such a way that the content did not challenge the experience of those living in the present. Simultaneously, it was an attempt to put up a distance from the representation of specific experiences of the living generation, and to create an opportunity to convey all the experiences in a new form.

Many speeches made by official representatives of the government at the tomb of the Unknown Soldier clearly testify to the fact that the rulers in the 1930s had chosen a strategy not to suppress the diversity of fighters for freedom, but rather subjugate it to their own interests, presented as an aspiration for national unity. In 1935, in the commemoration of the National Holiday, the minister for national defence Petras Šniukšta emphasised in his speech:

Here, gathered by the Tomb of the Unknown Soldier, we remember our heroes who gave their lives for Lithuania to be free [...]. Much was sacrificed before our homeland got rid of the foreign yoke. Many Lithuanian fighters perished, not only in the land of Lithuania, but also in remote lands, in the fields of Siberia. ("Nežuvo Lietuva iki šiolei, dabar jos niekas nepargriaus!", 1935, p. 3)

3 The bones were found in a farmer's field in Latvia, near Eglaine on the border with Lithuania. The organisers of their transport later recalled that they had no information allowing them to attribute the bones to a Lithuanian soldier. Cf. Jakštas, 1989, p. 14; "Pilkuosius karžygius prisiminus", 1934. 
On 16 February 1939, the commander of the Lithuanian army General Stasys Raštikis, a person close to Smetona, said that, by paying homage to the Unknown Soldier, we also pay homage to "all soldiers who perished in battles with the enemies of Lithuania, all the deceased veterans, workers, and fighters of our nation" ("Vasario 16 iškilmès Kaune”, 1939, p. 4).

What changed after all with the appearance of the Unknown Soldier, a symbol that had emerged in Europe from the experience of the First World War? First, after the Unknown Soldier had been buried in the garden of the War Museum, paying homage to him became the main feature of the whole ritual, although it was basically the same place as the visually unchanged Monument to Those who Perished for the Freedom of Lithuania. The "Leader of the Nation" started attending parades in the garden of the War Museum, while the platform with Smetona and others was arranged in such a way that the participants in the parade could see both the Tomb of the Unknown Soldier and Smetona: two symbols intended to unite the nation.

Second, with the appearance of the Tomb of the Unknown Soldier as a consolidating symbol, the formation of the garden of the War Museum acquired continuity. In 1938-1940, a series of new sculptural busts appeared, both of the representatives of the second storyline, that is, the founders of the Lithuanian army and the Lietuvos šauliu sajunga, the first soldier and the first officer who died for freedom, and of the obvious representatives of the first storyline, Petras Vileišis and Martynas Jankus, who on this occasion were again called veterans of the nation ("Tautos švente Kaune", 1939, p. 3). Moreover, a commemoration of the tenth anniversary of Basanavičius' death was held on the eve of 16 February 1937, during which a wreath was laid on the Tomb of the Unknown Soldier (Algim., 1937, p. 1), and in 1939, a yard of the "period of the press ban" started to form in the garden, with the sculptures The Book Smuggler, The Lithuanian School and The Sower. Thus, broad opportunities opened up to represent the first storyline.

And finally, let us recall the fact that, since 1937, the area of the Tomb of the Unknown Soldier and the War Museum was used almost every year as a site for congresses and meetings of different fighters for freedom each time. In September 1937, on the eve of the National Holiday, the Congress of the Movement of Lithuanian Soldiers in Russia in 1917-1919 opened in Kaunas to commemorate its twentieth anniversary; ceremonies also took place with the participation of Smetona in the garden of the War Museum by the Tomb of the Unknown Soldier ("Lietuvių karių Rusijoje 1917-19 m. sąjūdžio...”, 1937, p. 2; “Lietuvių karių Rusijoje sąjūdžio...”, 1937, p. 8). After the meeting, Great War veterans who served in Lithuanian national units operating in Russia in 1917-1919 founded the Kariuomenès pirmūnų sąjunga (Association of Army Predecessors). The emergence of this organisation obviously challenged the exceptional prioritisation of veterans of the Wars of Independence, chosen after the coup of 1926. During the congress, Smetona himself acknowledged that Lithuanian soldiers who 
died while serving in national units that were created during the Great War should also be considered as those "who sacrificed their lives for Lithuania". Besides, it was Smetona who suggested the title Army Predecessors to the new organisation ("Didžiais žygiais ir didžiais darbais tauta rašo sau istoriją", 1937, p. 25). It is hardly surprising that, a year later, as if to assert their supremacy, the Lietuvos kariuomenes savanorių sąjunga (established in January 1927) held a similar congress, and even tried to appropriate the Tomb of the Unknown Soldier, by calling him "their own comrade" ("Savanoriai kürèjai...", 1938, p. 3). Smetona attended it, too, and made a speech in which he emphasised the significance of the creators-volunteers (kürejai-savanoriai), as members of the Lietuvos kariuomenes savanorių sąjunga started to call themselves in the early 1930s. And even though one of the main streets in Kaunas was named Savanoriu (Volunteer) Avenue on the occasion of the Congress ("Kaunas gavo Savanoriu prospektą", 1938, p. 4), in his speech to creators-volunteers, the "Leader of the Nation" did not forget to name other fighters for the freedom of Lithuania. ${ }^{4}$ Finally, in November 1938, on the eve of Army Day, a general congress of the Lietuvos laisvès kovų invalidų sąjunga (Invalids Association of the Lithuanian Fight for Freedom) took place, in which the exclusive right to pay homage to the Tomb of the Unknown Soldier at the Vytautas the Great Museum was granted to an organisation that included veterans of both the Great War and the Wars of Independence (Agaras, 1938, p. 5).

In addition, since 1937, the Lietuvių-prancūzų draugija (Lithuanian-French Society) held a ceremony at the Tomb of the Unknown Soldier for three years in a row to pay homage to Lithuanian and French soldiers who died in the Great War; it took place each time on 11 November, a clear reference to the anniversary of the Armistice signed at Compiègne (cf. LCVA 945-1-39-27 1938; LCVA 945-1-39-5 1939; LCVA 945-1-66-6 1939). The interest of that organisation, established in 1923, in holding ceremonies seems to have been encouraged by a coincidence of internal and external circumstances. In the mid-1930s, at a time when Lithuania started reorienting its foreign policy by gravitating from Germany towards a French-proposed collective security system, the Board of the Society also changed. The chair was taken over by Mykolas Römeris (a veteran of the Great War and rector of Vytautas Magnus University) and Marija Urbšiene, the only author who wrote professionally on the theme of the Great War in interwar Lithuania, and who happened to be the wife of Juozas Urbšys, the director of the Political Department at the Ministry of Foreign Affairs, and a First World War veteran.

4 According to Smetona, "The Aušrininkai, Varpininkai and Sargininkai [contributors to Auszra, Varpas and Tévynés Sargas], in writing or in living word or deed, prepared the liberation of our Motherland. Without them, the consciousness of the nation would hardly have manifested itself during the Great War, and Lithuanians would hardly have grabbed the weapon and demanded freedom for themselves" (Smetona, 1938, p. 3). 
In the mid-1930s, when tensions over the Klaipeda region (Memel territory) began to emerge in Lithuania's relations with Germany, the Lithuanian press started actively publishing memoirs about the German occupation in the First World War, and most portrayed it (and Germans) in an exceptionally negative light. And there were grounds for this. In the early 1920s, in the foreword to his book of cartoons, Jaroslavas Rimkus wrote (Šilietis, 1922, p. iv): "It was very easy to collect material for this book, because every Lithuanian who lived under the German occupation seemed to be an unending source of information about German cruelty and misdeeds". At the same time that the memoirs of these atrocities were published in large quantities in newspapers, magazines, late issues of Karo archyvas, or the book of memoirs collected by Petras Ruseckas "Lithuania in the Great War" (Ruseckas, 1939), the Lietuvių-prancūzų draugija made attempts to remind everybody of the common participation by Lithuanian and French soldiers in the Great War. In that case, the setting up of a special department in the Vytautas the Great War Museum devoted to the history of Lithuanian units in Russia during the Great War in 1936 (Naujaliene et al., 2011, p. 55), and the organisation of the Kariuomenès pirmūnų sąjunga a year later, looks like part of the same trend. It had to emphasise the experiences not of all Lithuanian soldiers, but merely of soldiers who fought in the Russian army (i.e. against Germany) and formed Lithuanian units (i.e. they fought as representatives of Lithuania, although it was only imagined at the time). In this way, the message seemed to be spread that Lithuanians also fought in the Great War. Besides, they did so on the "right" side.

\section{Concluding remarks}

The material provided here proves that the image of the participants in the Wars of Independence as the main fighters for the freedom of Lithuania who allegedly received the most attention in the interwar period should be seriously revised. The Wars of Independence, even if they did overshadow something, were a common source of experience in specific communication milieus, and primarily in ones embracing part of the army and the Lietuvos šaulių sąjunga. However, the representation in the public discourse of the two other storylines that highlighted the contribution of alternative fighters to the freedom of Lithuania can be observed all through the interwar period. Thus the story about the fight for Lithuania during the Great War never disappeared from the public discourse in interwar Lithuania. The related experiences spread, and at the end of the 1930s that dissemination was even promoted to a certain controlled extent. The fact that these experiences were not on the priority list of organisations such as the Lietuvos šaulių sąjunga, which initiated probably the largest number of monuments, is another issue that has a particular explanation. Still, in my opinion, 
the roots of the explanation should be sought not in the Wars of Independence as such, but in the coup of 1926, and the power conjuncture that formed in the country afterwards.

However, in the evaluation of that power conjuncture, we should not forget the fact that Smetona and Voldemaras, who came to power after the coup, possessed different capitals for their moral and historical legitimacy. Voldemaras did not have the experience of a "fighter" for freedom, either before the First World War or during it, and he became involved in the activities of the Council of Lithuania after 16 February 1918. That may have led to his rapprochement with the freedom fighters whose organisation he felt he contributed to: the army, which started to form on a volunteer basis in 1918, and the influential Lietuvos kariuomenès savanorių sąjunga, which was made up of veterans of the army. It may present another explanation of the fact that after Voldemaras was made to step down in September 1929, the exceptional attention paid just after the coup to the memory of the fighters for independence of 1919-1920 slackened somewhat. In turn, Smetona accumulated his political capital in the years of the First World War and before it; moreover, since 1917, he had presided over the Council of Lithuania. That is why his feelings for the freedom fighters of 1919-1920 might not have been so strong. He and his circle preferred Vytautas the Great or Kęstutis, symbols that could be attached to alternative storylines or heroes of the distant past, who were in no way related to the individual experience of the contemporary generation.

In this situation, more opportunities appeared in the public discourse for the manifestation of Great War-related experiences in the fight for freedom. The emergence of the Tomb of the Unknown Soldier (1934) by the main monument in the garden of the War Museum, the Monument to Those who Perished for the Freedom of Lithuania, allowed the narrow and specific link of the symbol with the Wars of Independence to be significantly expanded. From that time on, all those who wanted to pay their respects to those who died in the Great War could also come to the symbol. The rallying of Lithuanian soldiers who at the end of the First World War started forming national units in Russia into an organisation to which Smetona himself gave the provocative name of Army Predecessors in 1937, became a challenge to creators-volunteers. Things were close to seeking the national memory of the Great War through the Kariuomenès pirmūnu sąjunga, given the number of influential civil service officials and especially top military leadership brought together by the association. In its constituent assembly in 1937, the association considered a specific action plan, which included: (a) the development of a publication about Lithuanian soldiers who served in Lithuanian national units operating in Russia in 1917-1919; (b) the construction of a "huge" monument to "all Lithuanians who perished in the World War", and (c) the production of a special medal for the participants in the 1917-1919 movement of Lithuanian soldiers in Russia (Senkus, 1937, p. 408). 
However, Lithuania's incorporation into the USSR in the summer of 1940 determined that the only thing that was achieved in all this plan was the production of the Army Predecessors' Medal.

Finally, Great War-related experiences of the struggle for Lithuania was the area that Smetona deservedly felt to have contributed to. In the years of the authoritarian regime, placing an emphasis on the significant contribution by the Council of Lithuania led by Smetona to the freedom of Lithuania, and 16 February presented as the most important expression of that freedom, was all essentially an appeal to the First World War. All this results in the somewhat different understanding of the statements made in the semi-official Lithuanian organ ("Sukaktuvių mintys", 1934, p. 4), such as "Our own freedom was born from the Great War”.

\section{Archival sources}

KAA 219-1-90-11/12. 1919. [Kaunas Regional State Archives, f. 219, ap. 1, b. 90, 1. 11-12]. The protocol of the joint meeting of the Kaunas City Council and the Commission for the Renaming of Streets, April 2, 1919.

LCVA 379-2-567-48/50. 1922. [Lithuanian Central State Archives, f. 379, ap. 2, b. 567, 1. 48-50]. The protocol of the Kaunas City Council meeting, February 13, 1922.

LCVA 923-1-68-58 1919. [Lithuanian Central State Archives, f. 923, ap. 1, b. 68, 1. 58]. Order of the Lithuanian Government, April 29, 1919.

LCVA 945-1-39-27. 1938. [Lithuanian Central State Archives, f. 945, ap. 1, b. 39, 1. 27]. Annual Report of the Lithuanian-French Society from 25 June 1937 to June 15, 1938.

LCVA 945-1-39-5. 1939. [Lithuanian Central State Archives, f. 945, ap. 1, b. 39, 1. 5]. Annual Report of the Board of the Lithuanian-French Society from 15 June 1938 to June 15, 1939.

LCVA 945-1-66-6. 1939. [Lithuanian Central State Archives, f. 945, ap. 1, b. 66, 1. 6]. The Board of the Lithuanian-French Society to the Minister of Foreign Affairs, December 12, 1939.

\section{Bibliography}

A. G. (1935, November 24). Visa Lietuva prie Nežinomojo kareivio kapo. Lietuvos aidas, p. 3. Agaras, A. (1938, November 23). Iš Lietuvos Laisvès Kovų Invalidų Draugijos suvažiavimo. Lietuvos aidas, p. 5.

Algim. (1937, February 16). Iškilmingai paminèta Dr. J. Basanavičiaus mirties sukaktis. Lietuvos aidas, p. 1.

Alm. (1930, November 24). Vytauto Didžiojo muziejus jau pradètas statyti. Lietuvos aidas, p. 5. Antanavičiūtè, R. (2016). The memory and representation of World War I in Lithuania. In G. Jankevičiūtè \& R. Žukienè (Eds.), The art of identity and memory: Toward 
a cultural history of the two world wars in Lithuania (pp. 175-202). Boston, MA: Academic Studies Press.

Baisus isspejimas. (1929, May 13). Lietuvos aidas, p. 1.

Balkelis, T. (2014). Memories of the Great War and the Polish-Lithuanian conflict in Lithuania. In E. Lohr, V. Tolz, A. Semyonov, \& M. von Hagen (Eds.), The empire and nationalism at war (pp. 241-256). Bloomington, In Slavica Publishers. (Russia's great war and revolution, 2).

Burba, S. V. (Ed.). (1928). Vasario 16 d.: 1918-1928 m. Vienkartinis leidinys Lietuvos Nepriklausomybès 10-ties metu sukaktuvés minint. Kaunas: (n.p.).

Čiabuvis. (1924, May 7). Mūsų periodinè spauda. Rytas, p. 1.

Daktarui Basanavičiui paminklo atidarymas. (1923, November 23). Lietuva, p. 1.

Didžiais žygiais ir didžiais darbais tauta rašo sau istoriją: Valstybės Prezidento Antano Smetonos kalba, pasakyta lietuvių karių Rusijoje sąjūdžio 20 metų sukakčiai paminèti (rugsẻjo 8 d. Karo muziejus). (1937). Lietuvos karo invalidas, 1937(1), 25.

Didžioji Tautos šventè. (1930, September 9). Lietuvos aidas, p. 4.

Drausminga kariuomenè ir drausminga tauta. (1937, November 23). Lietuvos aidas, p. 4.

Gabrys, J. (1928, February 15). Dešimčiai metų mūsų nepriklausomybės sukaktuvėms. (Žodis visuomenei vieno Lietuvos veteranų). Rytas, p. 4.

Gegužès 15 d. iškilmès Kaune. (1928, May 16). Lietuvos aidas, pp. 2-3.

I sesijos Pirmasai posèdis. (1920). Steigiamojo Seimo darbai, 1920(1), 1-5.

Isakymas Kariuomenei. (1920, February 4). 1920(232).

Isakymas Kariuomenei. (1921, January 22). 1921(17).

Isakymas Kariuomenei. (1922, January 14). 1922(10).

J. K. (1928, February 17). 10 metų Nepriklausomybės iškilmės Kaune. Lietuvos aidas, pp. 3-5.

J. S. (1934, November 29). Nežinomasis Kareivis palaidotas iškilmingai. Trimitas, 1934(48), 920.

Jakštas, P. (1989). Amžinybès vainikas. Nemunas, 1989(2), 12-15.

Janušauskaitè, I. (2016). Pirmasis lietuviškos spaudos atgavimo minejjimas nepriklausomoje Lietuvoje 1929 metais. Knygotyra, 67, 45-63. https://doi.org/10.15388/Knygotyra.2016.67.10176

Jeigu vienybejje su vyriausybe, visi persièmę Tẻvynès meilę, ištikimai ir drausmingai dirbsime ir nebijosime net mirti dèl Tẻvynès, tai tikrai mūsų Tẻvynè išliks nepriklausoma ir laiminga per ilgus amžius. (1934, November 24). Lietuvos aidas, p. 4.

Jurevičiūtè, A. (2009). Savanorių kūrèjų vienijimosi idejjos iggyvendinimas 1926 metų rudenį. Parlamento studijos, 2009(8), 87-106.

Kaip mūsų kariuomenè praleido vakarykščią dieną. (1927, November 24). Lietuva, p. 5.

Kaip praejo kariuomenès šventė. (1928, November 26). Lietuvos aidas, p. 4.

Kalnėnas, J. (1928). 10 ir 5. In A. Marcinkevičius (Ed.), 1928 m. vasario 16.10 mety Lietuvos nepriklausomybès sukaktuvems paminèti (pp. 141-159). Kaunas: Lietuvos šaulių sąjunga.

Kariuomenès 15-os metų sukaktis. (1933, November 23). Lietuvos aidas, p. 4.

Karo istorijos reikalu. (1922, February 16). Lietuva, p. 2.

Kaunas gavo Savanorių prospektą. (1938, September 9). Lietuvos aidas, p. 4. 
Kemežys, V. (Ed.). (1938). Lietuva 1918-1938: Leidinys 20 metu Lietuvos nepriklausomybès sukakčiai paminèti. Kaunas: Spaudos fondas.

Knygos, raštai. (1924). Trimitas, 1924(170), 47.

Lietuvių karių Rusijoje 1917-19 m. sąjūdžio dalyvių 20 metų sukakčiai paminèti suvažiavimas. (1937, September 8). Lietuvos aidas, p. 2.

Lietuvių karių Rusijoje sąjūdžio dalyvių suvažiavimo iškilmès. (1937, September 9). Lietuvos aidas, p. 8.

Liulevicius, V. G. (2009). Building nationalism: Monuments, museums, and the politics of war memory in inter-war Lithuania. In J. Tauber (Ed.), Über den Weltkrieg hinaus: Kriegserfahrungen in Ostmitteleuropa 1914-1921 (pp. 230-247). Lüneburg: Nordost-Institut. (Nordost-Archiv, NF Bd. XVII/2008).

Mačiulis, D. (2001). Vytauto Didžiojo metų (1930) kampanijos prasmè. Lituanistica, 46(2), 54-75.

Mačiulis, D. (2009). Apie dvi propagandines kampanijos XX a. tarpukario Lietuvoje. Inter-studia humanitatis, 9, 119-139.

[Markevičaite, J., \& Gira, L.]. (Eds.). (1921). Lietuvos albumas. Kaunas: (n.p.).

Mažrimas, E. (1994). Lietuvos partizanų paminklas. In M. Skirmantienė \& J. Varnauskas (Eds.), Nukentèję paminklai (pp. 177-178). Vilnius: Mokslo ir enciklopedijų leidykla.

Merkelis, A. (1938). Antanas Smetona - Schöpfer und Führer des unabhängigen Litauen. In S. Vykintas (Ed.), Litauens Werden und Schaffen (pp. 9-21). Kaunas: Oberste Komitee zur Feier des 20jährigen Jubiläums Litauens.

Naujalienè, D., Pūkys, A., Stoliarovas, A., Jurevičiūtè, A., Jankūnas, A., \& Markūnas, A. (2011). Vytauto Didžiojo karo muziejaus svarbiausiųjų įvykių kronika: 1919-1951 metai. In Vytauto Didžiojo Karo muziejaus 2010 metais almanachas (pp. 8-88). Kaunas: Vytauto Didžiojo karo muziejus.

Nepriklausomybės sukaktuvės Kaune. (1927, February 17). Lietuva, p. 4.

Nežuvo Lietuva iki šiolei, dabar jos niekas nepargriaus! (1935, September 9). Lietuvos aidas, p. 3.

Nikžentaitis, A. (1998). LDK kultūrinès tradicijos praradimas: Vytauto Didžiojo kultas Lietuvoje XIX-XX a. In R. Repšienè (Ed.), Senosios raštijos ir tautosakos squveika: Kultūrinè Lietuvos Didžiosios Kunigaikštystès patirtis (pp. 324-334). Vilnius: Lietuvių literatūros ir tautosakos institutas.

Nikžentaitis, A. (2002). Vytauto ir Jogailos įvaizdis Lietuvos ir Lenkijos visuomenèse. Vilnius: Aidai. Pilkuosius karžygius prisiminus. (1934). Kardas, 1934(23), 469-470.

Pirmoji karo auka nepriklausomai tėvynei. (a.a. Povilui Lukšiui atminimui). (1920, February 15). Lietuva, p. 5.

Pirmoji karo auka už nepriklausomą tèvynę. (a.a. Povilo Lukšio atminčiai). (1920). Kariškių žodis, 1920(12), 51-52.

Pirmųjų kraujo aukų sukaktuvės. A.a. kareivio Lukšio ir karininko Juozapavičiaus paminèjimas. (1927, February 17). Lietuva, pp. 2-3.

Plechavičius, P. (1928, November 24). Sukaktuvių proga. Lietuvos aidas, p. 2.

Rt. (1924, May 7). Po dvidešimt metų. Lietuva, pp. 1-2. 
Ruseckas, P. (Ed.). (1939). Lietuva Didžiajame kare. Vilnius: Vilniaus žodis.

Š. Š. (1924). Didijji Karą beminint. Trimitas, 1924(199), 10-12.

Safronovas, V., Jokubauskas, V., Vareikis, V., \& Vitkus, H. (2018). Didysis karas visuomeneje ir kultūroje: Lietuva ir Rytų Prūsija. Klaipėda: Klaipėdos universiteto leidykla.

Šapoka, A. (1938). Die Geschichte Litauens zweiter Teil. In S. Vykintas (Ed.), Litauens Werden und Schaffen (pp. 97-125). Kaunas: Oberste Komitee zur Feier des 20jährigen Jubiläums Litauens.

Sarafinas, H. (Ed.). (1933). Vytauto Didžiojo mirties 500 metu sukaktuvèms paminèti albumas, 1430-1930. Kaunas: (n.p.).

Savanoriai kūrẻjai nusilenkia savo kovų draugui Nežinomajam kareiviui. (1938, September 8). Lietuvos aidas, p. 3.

Senkus, J. (1937). Didysis karių suvažiavimas Tautos šventès metu. Kardas, 1937(18), 406-409.

Senn, A. E. (1977). The activity of Juozas Gabrys for Lithuania's independence, 1914-1920. Lituanus, 23(1), 15-22.

Šiandien 20 m. suejo, kaip Lietuva laimèjo ilgų metų kovą su Rusija del savo spaudos laisvès. (1924, May 7). Lietuvos žinios, p. 1.

Šilietis, J. [Rimkus, J.]. (1922). Vokiečiu okupacija Lietuvoje 1915-1919 m. paveikslèliuose ir trumpuose ju aprašymuose [The German occupation in Lithuania 1915-1919 related in pictures and short descriptions]. Kaunas: Varpas.

Sirutavičius, V. (2001). Šventès nacionalizavimas: “Tautos šventės” atsiradimas Lietuvos Respublikoje XX amžiaus 4-ajame dešimtmetyje. In V. Sirutavičius \& D. Staliūnas (Eds.), Nacionalizmas ir emocijos (Lietuva ir Lenkija XIX-XX a.) (pp. 120-132). Vilnius: LII leidykla. (Lietuvių Atgimimo istorijos studijos, 17).

Skirmantienè, M., \& Varnauskas, J. (Eds.). (1994). Nukentėję paminklai. Vilnius: Mokslo ir enciklopedijų leidykla.

[Smetona, A.]. (1930, October 28). Būkime Vytautiškai pasiruošę. Respublikos Prezidento kalba. Lietuvos aidas, pp. 1-2.

[Smetona, A.]. (1933, November 25). Valstybès Prezidento kalba prie laisvės Paminklo lapkričio 23 d. Lietuvos aidas, p. 1.

[Smetona, A.]. (1934). Valstybės Prezidento kalba, laidojant Nežinomąji Kareivị lapkričio 23 d. Kardas, 1934(23), 468.

[Smetona, A.]. (1938, September 9). Karių savanorių vaidmuo nèra baigtas. Respublikos Prezidento Antano Smetonos kalba, pasakyta rugsèjo 7 d. Savanorių Kūrèjų suvažiavime. Lietuvos aidas, p. 3.

Spalių 27 d. Kaune. (1930, October 28). Lietuvos aidas, p. 5.

Spaudos sukaktuvès. (1924). Trimitas, 1924(186), 1-2.

Staliūnas, D. (2001). Žuvusių karių kultas tarpukario Lietuvoje. In V. Sirutavičius \& D. Staliūnas (Eds.), Nacionalizmas ir emocijos (Lietuva ir Lenkija XIX-XX a.) (pp. 120-132). Vilnius: LII leidykla. (Lietuvių Atgimimo istorijos studijos, 17).

Staliūnas, D. (2008). Savas ar svetimas paveldas? 1863-1864 m. sukilimas kaip lietuvių atminties vieta. Vilnius: Mintis. 
[Stulginskis, A.]. (1921, October 18). Kalba pasakyta St. Seimo Pirmininko, E. Respublikos Prezidento Pareigas, A. Stulginskio, paminklą atidarant. Lietuva, p. 1.

Sukaktuvių mintys. (1934, August 3). Lietuvos aidas, p. 4.

Tautos šventė Kaune. (1939, September 7). Lietuvos aidas, p. 3.

Tautos šventès iškilmès. (1928, May 16). Rytas, p. 2.

Vasario 16 iškilmès Kaune. (1939, February 17). Lietuvos aidas, p. 4.

Vasiliauskas, [A]. (1938). Nepriklausomybės karas. In V. Kemežys (Ed.), Lietuva 1918-1938: Leidinys 20 metu Lietuvos nepriklausomybès sukakčiai paminèti (pp. 46-59). Kaunas: Spaudos fondas.

Viliūnas, G. (2001). Vytauto Didžiojo kultas tarpukario Lietuvoje. In V. Sirutavičius \& D. Staliūnas (Eds.), Nacionalizmas ir emocijos (Lietuva ir Lenkija XIX-XX a.) (pp. 68-102). Vilnius: LII leidykla. (Lietuvių Atgimimo istorijos studijos, 17).

Vorwort. (1938). In S. Vykintas (Ed.), Litauens Werden und Schaffen (pp. 5-6). Kaunas: Oberste Komitee zur Feier des 20jährigen Jubiläums Litauens.

Vygandas [Purickis, J.]. (1928). 10 metų Nepriklausomos Lietuvos. In A. Marcinkevičius (Ed.), 1928 m. vasario 16. 10 metu Lietuvos nepriklausomybès sukaktuvems paminèti (pp. 69-94). Kaunas: Lietuvos šaulių sąjunga.

Vykintas, S. (Ed.). (1938). Litauens Werden und Schaffen. Kaunas: Oberste Komitee zur Feier des 20jährigen Jubiläums Litauens.

Yčas, M. (1930). Rusijos lietuvių pastangos kovose už Lietuvos nepriklausomybę. In Pirmasis nepriklausomos Lietuvos dešimtmetis 1918-1928 (pp. 21-33). Kaunas: Vyriausias Lietuvos Nepriklausomybės 10 metų sukaktuvėms ruošti komitetas.

\title{
Who fought for national freedom? On the significance of the Great War in interwar Lithuania
}

\begin{abstract}
Even though the First World War was caused by tension in the east of Europe, not so long ago, quite a number of historians, as if repeating the words of Winston Churchill, tended to portray the Eastern Front in Europe as an "unknown war". Not only was the war in the east little known, but the remembrance of the war in Eastern Europe remains little investigated. Lithuania is one of the countries in the region where for a long time nothing was known about the remembrance of the Great War. Many historians argued that this kind of remembrance simply did not exist. The article invites us to reconsider this statement by paying attention to the question of how the merits of different actors in the struggle for national freedom were interpreted and represented in interwar Lithuania. Instead of painting a monolithic picture of
\end{abstract}


Lithuania, the article proposes to look at its society as a fragmented construct, whose different parts offered a rather ambiguous answer to the question.

Keywords: First World War; Wars of Independence; historical storyline; commemoration; politics of memory; idea of freedom

\section{Kto walczył o niepodległość? O interpretacji znaczenia I wojny światowej na Litwie w okresie międzywojennym}

\section{Streszczenie}

Pomimo że I wojna światowa była wynikiem napięć w Europie Wschodniej, to jeszcze niedawno wielu historyków opisywało działania na froncie wschodnim jako „nieznaną wojnę", nawiązując tym samym do słów Winstona Churchilla. Zaniedbanym obszarem badań była nie tylko sama wojna na Wschodzie, lecz również pamięć o niej w tej części kontynentu. Litwa jest jednym z krajów regionu, gdzie pamięć o Wielkiej Wojnie długo pozostawała zjawiskiem zupełnie nieznanym, a wielu historyków dowodziło, że takiej pamięci po prostu nie ma. Niniejszy artykuł zachęca do zrewidowania tej opinii i zwraca uwagę na kwestię oceny i interpretacji zasług różnych uczestników walk o niepodległość Litwy w okresie międzywojennym. Artykuł proponuje spojrzenie na litewskie społeczeństwo nie jak na monolit, lecz fragmentaryczny konstrukt, w którym różne środowiska udzielały różnych odpowiedzi na postawione w tytule pytanie.

Słowa kluczowe: I wojna światowa; wojny o niepodległość Litwy; narracja historyczna; upamiętnienie; polityka pamięci; idea wolności

Dr Vasilijus Safronovas, Research Professor at the Institute of Baltic Region History and Archaeology of Klaipeda University. He has published widely on issues of memory, identity, nationalism, mental geography, conceptual history, and cultural contact. His record of publication includes several books and over forty articles in academic journals and collected volumes published in Lithuanian, Polish, German, French, Russian and English. He is also editor or co-editor of eleven collected volumes. From June 2018, he has been head of the Institute of Baltic Region History and Archaeology of Klaipeda University. 
Bibliography (selected): О тенденциях политики воспоминания в современной Литве [Directions in the politics of memory of contemporary Lithuania], Ab Imperio 3, Kazan 2009, 424-458; Coming to terms with the dictatorial past: Rising of conservative trend in contemporary Lithuania, Transitional justice and politics of memory in Europe (Studia Universitatis Cibiniensis. Series Historica, Vol. 11/2014, Supplement), Sibiu 2014, 133-162; Kampf um Identität. Die ideologische Auseinandersetzung in Memel/ Klaipeda im 20. Jahrhundert [Struggle over identity: The ideological conflict in Memel/ Klaipeda in the twentieth century], Wiesbaden 2015; The creation of national spaces in a pluricultural region: The case of Prussian Lithuania, Boston 2016; (editor), The Great War in Lithuania and Lithuanians in the Great War: Experiences and memories, Klaipèda 2017.

Correspondence: Vasilijus Safronovas, Institute of Baltic Region History and Archaeology, Klaipedda University, e-mail: safronovas@gmail.com

Support of the work: The research was partly supported by the Research Council of Lithuania (grant no. MIP-021/2015).

Competing interests: No competing interests have been declared.

Acknowledgements: During the implementation of the project "Remembrance of the First World War: A Comparative Analysis of Lithuania and East Prussia (before 1939)" at Klaipéda University the research has been partly supported by the Research Council of Lithuania (grant no. MIP-021/2015). The article is based on several presentations given at the conference "Lithuanians in the Great War and the Great War in Lithuania" (Nida, 2017) and the 12th Conference on Baltic Studies in Europe (Riga, 2017). I am grateful to Mindaugas Balkus from Vytautas Magnus University and Vytautas Jokubauskas from Klaipéda University for their help in searching sources for this article.

ORCID Vasilijus Safronovas http://orcid.org/0000-0003-0390-3056 